\title{
INFESTASI PENGGEREK BUAH KAKAO KEDALAM PERKEBUNAN KAKAO DI KAWASAN KERKAP, BENGKULU UTARA DAN PENGENDALIANNYA
}

\author{
Teddy Suparno ${ }^{1}$
}

\begin{abstract}
Infestation of cocoa pod borer into cacao plantation in kerkap area, north bengkulu and their control. Cocoa pod borer (CPB), Conopomorpha cramerella Snellen, has known as a primary pest on cacao plantation and caused much yield loss. This pest was newly infest into cacao plantation in Bengkulu Province. Objective of the research was to know infestation of CPB into Cacao Plantation in Kerkap area, North Bengkulu. The result showed that all location on cacao plantation area at Kerkap area was gain infestation by cocoa pod borer except the Cacao Plantation at Serumbung Village. Their attack on all plant population was in range between 0.01 and $0.23 \%$, while in produced plant population was in range between 0.20 and $3.06 \%$. The control could be apply are early pick up the pods, used the resistant clones for juvenilization, and spraying by synthetic.

Kata Kunci. Penggerek buah kakao, petik dini, klon tahan, piretroid sintetik
\end{abstract}

\section{PENDAHULUAN}

Menurut hasil pencatatan Dinas Perke-bunan Dati I Bengkulu (1999) luas keseluruhan tanaman kakao di Propinsi Bengkulu sekitar 13.952 hektar. Minimal 2.100 hektar di antaranya terdapat di wilayah Kecamatan Kerkap, Bengkulu Utara (PBS PT Kultindo Rezeki seluas 1.994 ha dan Kebun milik petani di Desa Serumbung).

Dalam pengembangan tanaman kakao selalu mendapatkan kendala serangan hama dan penyakit. Sampai tahun 1993, yang menjadi hama utama tanaman kakao di Propinsi Bengkulu adalah kepik penghisap buah kakao Helopeltis theobromae. Sejak September 1994 ditambah lagi masalah hama, yaitu masuknya penggerek buah kakao (PBK) Conopoomorpha cramerella Snellen. Hama PBK itu telah di-ketahui sebagai hama penting pada pertanaman kakao di Filipina, Sulawesi Utara, Maluku Utara, Jawa, Sumatera Utara, Sumatera Barat dan Sabah (Malaysia). Akibat serangan PBK dapat menurunkan produksi sampai $80 \%$ dan kerusakan biji sampai $82 \%$, sehingga ditakuti oleh petani dan pengusaha perkebunan kakao.
Kerusakan yang ditimbulkan oleh larva PBK berupa rusaknya biji, mengeriputnya biji dan timbulnya warna gelap pada kulit biji (Sahputra, 1989). Hal itu berarti turunnya berat dan mutu produk. Kerugian yang disebabkan oleh PBK merupakan resultante dari turunnya berat dan mutu produk serta meningkatnya biaya panen karena pemisahan biji sehat dari biji yang rusak memerlukan waktu lama. Untuk mengetahui kerusakan buah kakao akibat serangan PBK maka buah harus dikupas.

Dalam kehidupan tanaman kakao, sejarah hidup dan kesinambungan generasi PBK dapat digambarkan sebagai berikut. Telur berwarna kuning jingga, diletakkan satu per satu oleh ngengat betina pada alur-alur permukaan buah (Entwistle, 1985), terutama buah yang telah berukuran panjang di atas $8 \mathrm{~cm}$, dan tidak pada bagian lainnya. Setelah 6-7 hari, larva berwarna kekuningan yang panjangnya $1 \mathrm{~mm}$ keluar dari telur, langsung menggerek kedalam buah dan tetap tinggal di dalam buah sampai menjelang berkepompong. Larva membuat liang gerekan di bawah kulit buah dan di antara biji serta memakan daging buah. Pada buah yang relatif muda hal itu menyebabkan biji melekat pada kulit buah dan

\footnotetext{
${ }^{1}$ Dosen Program Studi Ilmu Hama dan Penyakit Tumbuhan, Fakultas Pertanian Universitas Bengkulu
} 
melekat satu sama lain, sedang pada buah matang tidak menimbulkan keru-sakan berarti pada biji tapi dapat menurunkan mutu biji. Gerekan pada buah muda menyebabkan biji tidak berkembang, lebihlebih apabila terjadi perusakan pada saluran makanan yang menuju biji (Wardojo, 1984).

Setelah 15-18 hari larva di dalam buah mencapai ukuran panjang 10-11 mm dan berwarna hijau pucat, membuat liang gerekan keluar, melekat pada permukaan buah atau menjatuhkan diri pada daun segar atau kering di atas tanah, lalu menjadi kepompong. Setelah 6-8 hari berkembang menjadi ngengat yang bertubuh ramping dan lembut, mempunyai panjang tubuh $7 \mathrm{~mm}$ dan rentangan sayap $12 \mathrm{~mm}$. Perkembangan PBK sejak diletakkan sebagi telur sampai mencapai stadium dewasa memerlukan waktu 27-33 hari (Wardojo, 1984). Menurut Lim (1984) keperidian ngengat betina PBK dapat mencapai 200 telur per betina Ngengat hanya aktif pada malam hari selama beberapa jam saja sejak matahari terbenam. Pada siang hari, ngengat berada di tempat teduh dan sering terdapat pada bagian bawah cabang horizontal, berdiri dengan arah tegak lurus pada arah sumbu cabang tersebut.

Setiap buah kakao dapat menunjang kehi-dupan PBK dari satu sampai tiga generasi. Lim (1984) dari hasil percobaan yang menggunakan 225 buah kakao, menemukan $72 \%$ menunjang satu generasi, 20.8\% buah (dua generasi) dan $7.11 \%$ buah (tiga generasi).

Tujuan penelitian ini adalah untuk mengetahui infestasi PBK kedalam pertanam-an kakao di Wilayah Kerkap, Bengkulu Utara.

\section{BAHAN DAN METODE}

Pengamatan dilakukan di pertanaman kakao yang sudah berbuah di PT. Kultindo Rezeki dan Perkebunan Rakyat Serumbung Kerkap, selama bulan Juni 1999. Untuk Perkebunan Besar milik PT swasta tersebut pengamatan dilakukan pada tiap afdeling yang mempunyai luas antara 240 - 274 hektar. Semua buah yang telah masak fisiologis dipetik dan dikupas untuk mengamati buah yang terserang PBK. Buah kakao yang terserang ditandai dengan warna agak jingga atau pucat keputihan, buah menjadi lebih berat dan bila diguncang tidak terdengar suara ketukan antara biji dengan dinding buah. Bila buah dikupas akan kelihatan biji lengket satu dengan lainnya. Peubah yang diamati meliputi: Persentase pohon terserang dari semua populasi pohon, persentase pohon terserang dari semua pohon yang telah berproduksi dan luas serangan. Persentase buah terserang dihitung dengan cara membagi jumlah pohon yang terserang dibagi dengan semua jumlah pohon yang diamati dikalikan seratus persen.

Tingkat serangan dapat dikategorikan berdasarkan ikatan biji kakao dan kulit buah yaitu dikelompokkan dalam tiga tingkat, infestasi ringan, sedang dan berat. Infestasi ringan jika daging buah sedikit rusak dan sebagian besar biji yang dihasilkan dalam kondisi baik, infestasi sedang jika sebagian plasenta mengalami pengerasan dengan 50\% biji tidak dapat dimanfaatkan, dan infestasi berat atau tinggi jika semua daging buah mengalami pengerasan tanpa biji berkondisi baik atau tidak ada biji yang dapat dimanfaatkan (Lim, 1984).

\section{HASIL DAN PEMBAHASAN}

Buah kakao yang mendapatkan serangan PBK terus dapat berkembang seolah-olah tidak terjadi serangan, sehingga buah yang terserang tidak ada perbedaan dengan buah kakao yang sehat. Gejala baru tampak dari luar setelah matang di musim panen, buah kakao yang terserang berwarna agak jingga atau pucat keputihan, buah menjadi lebih berat dan bila diguncang tidak terdengar suara ketukan antara biji dengan dinding buah. Hal itu teljadi karena timbulnya lendir dan kotoran pada daging buah dan rusaknya biji-biji di dalam buah. Kerusakan daging buah akibat serangan PBK disebabkan oleh enzim heksokinase, malat dehidrogenase, fluorescent esterase and malic enzyme polymorphisms yang disekresikan oleh PBK (Tan et al., 1988).

Kerusakan yang ditimbulkan oleh larva PBK berupa rusaknya biji, mengeriputnya biji dan timbulnya warna gelap pada kulit biji. Hal itu berarti turunnya berat dan mutu produk. Kerugian yang disebabkan oleh PBK merupa-kan resultante dari turunnya berat dan mutu produk serta meningkatnya biaya panen karena pemisahan biji sehat dari biji yang rusak memerlukan waktu lama.

Sesuai dengan ukuran tubuh yang kecil dan lembut, daya pencar PBK sangat terbatas. Penyebaran sampai jarak jauh hanya dapat terjadi secara pasif, yaitu sebagai larva di dalam buah atau sebagai kepompong pada permukaan buah atau bahan tanaman lain yang terbawa keluar dari tempat sumber hama. Dari studi pustaka dapat diketahui bahwa 
masalah hama PBK mula-mula timbul di tanaman kakao di Filipina sekitar tiga abad yang lalu, kemudian di Sulawesi Utara pada tahun 1841 atau jauh sebelumnya, sedang di Jawa Tengah baru pada tahun 1895 (Wardojo, 1980). Hal itu terjadi sejalan dengan pengiriman bahan tanaman kakao Criollo berulang kali, terutama berupa biji di dalam buah kakao dari Filipina ke Sulawesi utara, kemudian ke Maluku dan Jawa. Penyebaran ke bagian Indonesia lainnya, yaitu Jawa Timur (1901), Jawa Barat (1956), Sumatera Utara (1957), diperkirakan sejalan dengan penyebaran bahan tanaman berupa klon Djati Roenggo (DR) dari Jawa Tengah sejak akhir abad lalu. Pemasukan buah kakao yang sebagian mungkin mengandung PBK kedalam pertanaman yang telah berproduksi, di masa yang lalu dilakukan dalam rangka perluasan areal pertanaman (periode penyebaran Criollo) dan dalam rangka penanaman kakao berpotensi produksi tinggi dan tahan terhadap penyakit (periode penyebaran klon DR dan klon lain). Dari kasus yang diketahui sampai sekarang, infes-tasi PBK di suatu kebun biasanya didahului oleh pemasukan bahan tanaman yang berasal dari sumber hama. Diperkirakan bahwa hal itu juga terjadi di

Tabel Pohon Kakao terserang PBK pada 1. Bulan Juni 1999

\begin{tabular}{cccc}
\hline Afdeling & $\begin{array}{c}\text { Populasi } \\
\text { Pohon }\end{array}$ & $\begin{array}{c}\text { Pohon } \\
\text { Terseran } \\
\mathrm{g}\end{array}$ & Persentase \\
\hline & & & \\
I & 177.310 & 53 & 0,03 \\
II & 173.050 & 24 & 0,01 \\
III & 170.137 & 80 & 0,05 \\
IV & 125.478 & 119 & 0,09 \\
V & 153.044 & 91 & 0.07 \\
VI & 146.997 & 26 & 0,02 \\
VII & 100.875 & 229 & 0,23 \\
\hline Total & 1.046 .891 & 622 & 0,06 \\
\hline
\end{tabular}

Penggerek buah kakao Conopomorpha cramerella adalah spesies asli Asia Tenggara yang hidup pada rambutan (Nephelium lappaceum L., Sapindaceae) dan namnam (Cynometra cauliflora L., Leguminosae). Adanya introduksi tanaman kakao dari Meksiko (oleh orang Spanyol) ke Filipina pada
Bengkulu yang mengalami infestasi PBK sejak September 1994.

Hama PBK masuk di Bengkulai pada bulan September 1994 di Kebun Kakao Pino Bengkulu Selatan milik PTPN VII Pino, dengan luas serangan 14 hektar, kemudian menyebar ke Kebun Kakao yang lain.

Perkebunan kakao di Kawasan Kerkap merupakan wilayah Propinsi Bengkulu yang terinfestasi hama PBK terakhir. Dari hasil pengamatan pada bulan Juni 1999 diketahui bahwa hama PBK sudah menginfestasi seluruh kebun atau afdeling PT Kultindo Rezeki, namun tingkat serangannya sangat rendah. Serangan untuk semua populasi pohon berkisar antara 0,01 - 0,23\% (Tabel 1), sedang untuk populasi pohon yang sudah bereproduksi saja berkisar antara 0,20 - 3,06\% (Tabel 2). Serangan di Kebun ini paling rendah bila dibandingkan dengan perkebunan-perkebunan besar swasta lainnya yang ada di Provinsi Bengkulu. Kebun milik Petani Desa Serumbung, Kerkap, Bengkulu Utara hingga saat ini belum terserang oleh hama PBK.

Tabel Persentase pohon berbuah terseran

2. $\quad$ PBK pada bulan Juni 1999

\begin{tabular}{crcc}
\hline \multicolumn{4}{c}{ Kebun sudah produksi } \\
$\begin{array}{l}\text { Afdelin } \\
\text { g }\end{array}$ & $\begin{array}{l}\text { Jumlah } \\
\text { pohon } \\
\text { diamati }\end{array}$ & $\begin{array}{l}\text { Jumlah } \\
\text { pohon } \\
\text { terserang }\end{array}$ & $\begin{array}{l}\text { Persentas } \\
\text { e }\end{array}$ \\
\hline & \multicolumn{3}{l}{} \\
I & 1.800 & 55 & 3,06 \\
II & 2.500 & 25 & 1,00 \\
III & 17.100 & 89 & 0,52 \\
IV & 12.999 & 143 & 1,10 \\
V & 10.636 & 117 & 1,10 \\
VI & 14.500 & 29 & 0,20 \\
VII & 105.700 & 296 & 0,28 \\
\hline Total & 165.235 & 754 & 0,46 \\
\hline
\end{tabular}

pertengahan abad 16, PBK beradaptasi pada tanaman kakao tersebut sebagai inang baru. Larva PBK juga ditemukan pada Cola (Cola nitida, Sterculiaceae), tanaman intro-duksi dari Afrika. Di Kawasan Kerkap terdapat banyak tanaman rambutan yang mempunyai pertumbuhan baik dan berbuah lebat. Apabila terjadi 
serangan Conopomorpha cramerella pada tanaman rambutan akan menjadi sumber serangan bagi pertanaman kakao di sekitarnya. Kekhawatiran ini tidak perlu ada, karena PBK yang menyerang tanaman rambutan dan kakao berbeda secra ras biologi (Wardojo, 1999).

Rendahnya tingkat serangan di Lokasi-lokasi kebun kakao di PT Kultindo Rezeki karena kebun itu dikelola dengan baik dan merupakan kebun kakao yang pengelolaan hamanya terbaik di Bengkulu. Pengendalian yang dilakukan adalah dengan petik dini, yaitu setiap minggu memetik buah kakao yang mulai masak. Setelah pecah buah, kulit buah yang terserang dibenam. Tindakan ini dikombinasi-kan dengan pembersihan serasah daun. Melakukan penyemprotan insektisida piretroid sintetik setiap dua minggu, diarahkan pada buah, cabang dan batang.

Untuk kebun yang masih bebas dari PBK seperti kebun kakao desa Serumbung perlu mengambil langkah sebagai berikut. Melakukan pengamatan kualitatif pada waktu pecah buah untuk mengetahui ada tidaknya gejala serangan PBK. Apabila ditemukan ditemukan gejala serangan segera melapor ke Dinas Perkebunan atau ke Laboratorium Protek Universitas Bengkulu. Dalam kondisi seperti sekarang tindak lanjut berupa eradikasi tidak dibenarkan apabila ada peluang terjadi serangan ulang dari luar. Eradikasi dengan cara rampasan, pangkasan cabang atau pembuangan bunga dianggap sebagai pengorbanan hasil yang terlalu besar. Seharusnya petani atau pengusaha melarang pedagang pengumpul masuk kebun dengan kendaraan dan wadah bekas yang mungkin mengandung kepompong PBK.

Untuk peremajaan harus digunakan klon yang tahan terhadap PBK, misalnya klon PA7, UA37, dan LAFI7 serta tipe Amelonado.

\section{KESIMPULAN}

Semua lokasi kebun kakao milik Perke-bunan Besar Swasta PT Kultindo Rezeki telah terinfestasi oleh hama PBK. Tingkat serangan pada semua populasi pohon berkisar antara 0,01 - 0,23\%, sedang pada populasi pohon yang sudah berbuah saja berkisar antara 0,20 - 3,06\%. Kebun kakao milik Petani Desa Serumbung hingga saat ini masih bebas dari hama PBK. Cara pengendalian yang dapat diterapkan adalah petik dini, menggunakan klon tahan PBK untuk peremajaan dan insektisida piretroid sintetik. Melarang pedagang pengumpul masuk kebun dengan kendaraan dan wadah bekas yang mungkin mengandung kepompong PBK.

\section{UCAPAN TERIMA KASIH}

Terima kasih disampaikan kepada direktur PT Kultindo Rezeki dan Suwardi petani kakao desa Serumbung yang telah memperkenankan penelitian di kebunnya.

\section{DAFTAR PUSTAKA}

Anonim, 1997. Lima tahun penelitian dan pengembangan pertanian 1992-1996. Menyongsong Era Globalisasi.

Bradley, J. D. 1986. Identity of the South-East Asian cocoa moth, Conopomorpha crame-rella (Snellen) (Lepidoptera: Gracilariidae), with descriptions of three allied new species. Bull. Ent. Res. 76: 41-51.

Entwistle, P. F. 1972. Pests of cocoa. Longman Group Ltd., London. 778 pp.

Lim, G. T. 1984 b. The behavioural studies on cocoa pod borer Acrocercops cramerella Snellen. 9th International Cocoa Research Conference, Togo. (1984): 539-542.

Suparno, T. 1990. Konsepsi penanggulangan penggerek buah kakao di Provinsi Beng-kulu. Seminar Penanggulangan OPT Penggerek Buah Kakao di Provinsi Bengkulu Tanggal 1 Agustus 1999. Disbun Dati I Bengkulu. 9 hal.

Tan, S. G, Muhamad, R., Gan, Y. Y. dan Rita, M. 1988. Hexokinase, malate dehydro-genase, fluorescent esterase and malic enzyme polymorphisms in the cocoa pod borer, Conopomorpha cramerella (Snel-len). Pertanika 11: 7-13.

Wardojo, S. 1984. Kemungkinan pembebasan Maluku Utara daripada masalah penggerek buah cokelat, Acrocercops cramerella Sn. Menara Perkebunan 52: 57-64.

dan Moersamdono. 1984. Kantung plastik untuk melindungi buah cokelat dari serangan 
Acrocercops cramerella Snellen. Menara Perkebunan 52: 77-83.

1992. Kemungkinan pembebasan Maluku Utara daripada masalah penggerek buah cokelat, Acrocercops cramerella Sn. Menara Perkebunan 52: 57-64.
1999. Konsepsi strategi penanggulangan penggerek buah kakao di Provinsi Bengkulu. Seminar Penanggulangan OPT Penggerek Buah Kakao di Provinsi Bengkulu Tanggal 1 Agustus 1999. Disbun Dati I Bengkulu. 7 hal. 